\title{
Understanding the aqueous phase ozonolysis of isoprene: distinct product distribution and mechanism from the gas phase reaction
}

\author{
H. L. Wang ${ }^{1}$, D. Huang ${ }^{1}$, X. Zhang ${ }^{1, *}$, Y. Zhao ${ }^{1}$, and Z. M. Chen ${ }^{1}$ \\ ${ }^{1}$ State Key Laboratory of Environmental Simulation and Pollution Control, College of Environmental Sciences and \\ Engineering, Peking University, Beijing 100871, China \\ *now at: Department of Environmental Science and Engineering, California Institute of Technology, Pasadena, \\ CA 91125, USA
}

Correspondence to: Z. M. Chen (zmchen@pku.edu.cn)

Received: 16 February 2012 - Published in Atmos. Chem. Phys. Discuss.: 1 March 2012

Revised: 18 July 2012 - Accepted: 30 July 2012 - Published: 7 August 2012

\begin{abstract}
The aqueous phase reaction of volatile organic compounds (VOCs) has not been considered in most analyses of atmospheric chemical processes. However, some experimental evidence has shown that, compared to the corresponding gas phase reaction, the aqueous chemical processes of VOCs in the bulk solutions and surfaces of ambient wet particles (cloud, fog, and wet aerosols) may potentially contribute to the products and formation of secondary organic aerosol (SOA). In the present study, we performed a laboratory experiment of the aqueous ozonolysis of isoprene at different $\mathrm{pHs}(3-7)$ and temperatures $\left(4-25^{\circ} \mathrm{C}\right)$. We detected three important kinds of products, including carbonyl compounds, peroxide compounds, and organic acids. Our results showed that the molar yields of these products were nearly independent of the investigated $\mathrm{pHs}$ and temperatures, those were (1) carbonyls: $56.7 \pm 3.7 \%$ formaldehyde, $42.8 \pm 2.5 \%$ methacrolein (MAC), and $57.7 \pm 3.4 \%$ methyl vinyl ketone (MVK); (2) peroxides: $53.4 \pm 4.1 \%$ hydrogen peroxide $\left(\mathrm{H}_{2} \mathrm{O}_{2}\right)$ and $15.1 \pm 3.1 \%$ hydroxylmethyl hydroperoxide (HMHP); and (3) organic acids: undetectable ( $<1 \%$ estimated by the detection limit). Based on the amounts of products formed and the isoprene consumed, the total carbon yield was estimated to be $94.8 \pm 4.1 \%$. This implied that most of the products in the reaction system were detected. The combined yields of both MAC + MVK and $\mathrm{H}_{2} \mathrm{O}_{2}+\mathrm{HMHP}$ in the aqueous isoprene ozonolysis were much higher than those observed in the corresponding gas phase reaction. We suggest that these unexpected high yields of carbonyls and peroxides are related to the greater capability of condensed water, compared to water vapor, to sta-
\end{abstract}

bilize energy-rich Criegee radicals. This aqueous ozonolysis of isoprene (and possibly other biogenic VOCs) could potentially occur on the surfaces of ambient wet particles and plants. Moreover, the high-yield carbonyl and peroxide products might provide a considerable source of aqueous phase oxidants and SOA precursors.

\section{Introduction}

Carbonyl and peroxide compounds are important trace components in the atmosphere. In recent years, these two compounds are paid more and more attention, because they form components or precursors of secondary organic aerosol (SOA) (e.g., Mochida et al., 2006; Tong et al., 2006; Hallquist et al., 2009), and they produce reactive radical oxidants, including $\mathrm{OH}, \mathrm{HO}_{2}$, and $\mathrm{RO}_{2}$ (e.g., Jacob, 1986; Atkinson and Arey, 2003). The gas phase ozonolysis of biogenic unsaturated volatile organic compounds (VOCs) was considered to be an important pathway that simultaneously formed carbonyls and peroxides (Atkinson and Carter, 1984; Becker et al., 1990; Gäb et al., 1995; Neeb et al., 1997; Sauer et al., 1999; Zhang et al., 2002; Chen et al., 2008). The yields of carbonyls and peroxides under humid conditions were significantly higher than those under dry conditions. However, few studies (Gäb et al., 1995; Chen et al., 2008) focused on the effect of condensed water on the formation of these products, when the contribution of the gas phase reaction was eliminated. Previously, Henry's law constant was considered to be the key parameter that determined the 
relative importance of the aqueous phase reaction of a compound; therefore, poorly-soluble volatile organic compounds (psVOCs), including biogenic isoprene and terpenes, were excluded in analyses of aqueous phase reactions. As a result, previous studies mainly focused on the aqueous chemical processes of water-soluble organic compounds (e.g., Monod et al., 2000; Carlton et al., 2006, 2007; Altieri et al., 2008; Perri et al., 2009; Schwier et al., 2010). Thus, little is known about the aqueous phase fate of psVOCs and their potential contributions to the formation of carbonyl and peroxide compounds (Zhang et al., 2009) and aqueous SOA in the atmosphere (Ervens et al., 2011).

In fact, aqueous phase reaction may occur in both the bulk solution and on the surfaces of atmospheric wet particles (cloud, fog, and wet aerosols), water bodies (sea, lakes, and rivers), and wet soils. Both reactions should be considered for soluble VOCs, but it seems that only the reactions occurring on the surface are important for psVOCs (Chen et al., 2008; Huang et al., 2011). Moreover, when biogenic VOCs, like isoprene and terpenes, are emitted from plant cells into the air through the wet surfaces of leaves, they first encounter gas phase oxidants (e.g., ozone and $\mathrm{OH}$ radicals) at the wet surface. Interestingly, Hewitt et al. (1990) found that hydroperoxides were formed on or in leaves when plants were exposed to ozone. These observed hydroperoxides had to be produced from chemical reactions, particularly surface reactions, because there is no significant primary peroxide source in the atmosphere (Jackson and Hewitt, 1996). Altimir et al. (2006) proposed that an aqueous reaction on the wet surface of plants was a potentially important chemical process for exchanging ozone between the forest canopy and the atmosphere. Based on those observations, we aim to investigate the aqueous reaction of biogenic VOCs to extend the current knowledge of the chemistry that takes place on the atmospheric surfaces of wet particles and plants.

New technology and methods, like laser induced fluorescence and spraying chambers, have been developed to explore aqueous surface reactions of organic compounds, like pyrene (Mmereki and Donaldson, 2002), and the ozonation of terpenes (Enami et al., 2010). However, it remains difficult to quantify the reaction products. Alternatively, a series of recent laboratory experiments on the aqueous oxidation of psVOCs in bulk water in the absence of gas phase interference were performed to quantitatively determine the effect of condensed water on the distribution of products that formed in the aqueous reaction of several psVOCs (Chen et al., 2008; Zhang et al., 2009, 2010; Huang et al., 2011; EI Haddad et al., 2009; Liu et al., 2009; Liu et al., 2012). Interestingly, those studies revealed that the production of carbonyls, organic acids, and peroxides in the aqueous ozonolysis of $\alpha$-pinene, $\beta$-pinene, methacrolein (MAC), and methyl vinyl ketone (MVK), and the aqueous $\mathrm{OH}$ radical-initiated oxidation of isoprene, MAC, and MVK significantly differed from those observed in the corresponding gas phase reaction. This suggests that a specific SOA would be produced in the aqueous phase because of the different distribution of SOA precursors (carbonyls, organic acids, and peroxides) compared to the corresponding gas phase. Moreover, several studies revealed that particle-associated semi-volatile organic compounds could be detected at a much higher concentration than predicted by gas to droplet or particle partition theory (Schweitzer et al., 1998; Liggio et al., 2005; Corrigan et al., 2008; Nguyen et al., 2010). Those results imply that the aqueous reaction of psVOCs merits a separate study that could more precisely evaluate the contributions of gas and aqueous phases to product yields.

In the present work, we are interested in the aqueous ozonolysis of isoprene, which is the most abundant biogenic VOC (Guenther et al., 2006). We aim to compare the mechanism of aqueous isoprene ozonolysis to that of the corresponding gas phase reaction, and to discuss related implications. During this process, we elucidated the precise chemical stoichiometry for the aqueous isoprene reaction with ozone, quantified the major products, including carbonyls, peroxides, and organic acids, and discussed whether the aqueous chemical processes of isoprene might be important for the production of SOA and the transformation of oxidants (Huang et al., 2011).

\section{Experimental}

A stock solution was prepared with isoprene (Fluka, 99.5\%) diluted in acetonitrile to a final concentration of $2 \mathrm{mM}$. Acetonitrile was used to assist isoprene to dissolve and disperse in water. In blank experiments, the mixture of water and isoprene stock solution was tested before the formal series of aqueous phase reactions were carried out. We ascertained that peroxides, carbonyl compounds, and organic acids were undetected in the stock solutions.

The experimental apparatus was described in detail in our previous work (Chen et al., 2008). The aqueous phase experiments were performed by mixing $495 \mathrm{ml} \mathrm{O}_{3}$ solution with $5 \mathrm{ml}$ isoprene stock solution in a 515 -ml quartz aqueous reactor in darkness at different initial pHs (7.0, 5.4, and 3.0), and temperatures $\left(4^{\circ} \mathrm{C}, 10^{\circ} \mathrm{C}\right.$, and $\left.25^{\circ} \mathrm{C}\right) . \mathrm{H}_{2} \mathrm{SO}_{4}$ was used to adjust the pHs. In the reactor, the concentration of isoprene was $\sim 20 \mu \mathrm{M}$ and the concentration of ozone was 2 to $10 \mu \mathrm{M}$. Ozone solution was obtained by passing gaseous ozone through a 1.01 water in a 2.11 quartz container. After $2 \mathrm{~h}$, the aqueous ozone concentration became stable. The stable ozone concentration was different at different temperatures, from 2 to $10 \mu \mathrm{M}$. Ozone was generated by irradiation of $\mathrm{O}_{2}$ ( $\geq 99.999 \%$, Beijing Analytical Instrument Factory, Beijing, China) at a flow rate of $100 \mathrm{ml} \mathrm{min}^{-1}$. The concentrations of ozone and the major products, including carbonyl compounds, peroxide compounds, and organic acids, were determined with methods described previously (Wang et al., 2009; Hua et al., 2008). Before mixing with isoprene solution, the aqueous ozone concentration was determined by 
indigo disulphonate spectrophotometry. After mixing, $5 \mathrm{ml}$ sample was extracted from the mixture at 5, 15, 30, 60, and $90 \mathrm{~min}$ for determining the concentrations of ozone, carbonyls, peroxides, and organic acids. After the sample was extracted, the sample was divided immediately into 4 parts for pretreatment or online analysis (within $2 \mathrm{~min}$ ): $1 \mathrm{ml}$ for determining the aqueous ozone; $1 \mathrm{ml}$ for the peroxides; $2 \mathrm{ml}$ for the carbonyl compounds; and $1 \mathrm{ml}$ for the organic acids. Peroxide compounds were online analyzed with high performance liquid chromatography (HPLC) (Agilent 1100, USA) coupled with post-column derivatization. In this step, the peroxides oxidized hydroxyphenylacetic acid to produce a fluorescent dimer in a reaction catalyzed by hemin. Carbonyl compounds were analyzed by mixing $2 \mathrm{ml}$ sample with $2 \mathrm{ml}$ 2,4-dinitrophenyhydrazine (DNPH)-acetonitrile solution for derivative and then for off line analysis of HPLC with UV detection (Agilent 1100, USA) after 12-24 h derivatization. Organic acids were analyzed with ion chromatography (DIONEX 2650, USA) and an ED50 conductivity detector. Considering the gas space above the liquid mixture in the quartz reactor, the upper limits for the loss of aqueous ozone and isoprene into the gas phase were estimated to be about $10.7 \%$ and $8.6 \%$, respectively, at $298 \mathrm{~K}$ based on their Henry's law constants (Sander, 1999). Therefore, the contribution of the gas phase reaction was mostly eliminated, and the reaction could be regarded as an aqueous phase reaction. A small amount of $\mathrm{H}_{2} \mathrm{O}_{2}\left(<10 \%\right.$ of the $\mathrm{H}_{2} \mathrm{O}_{2}$ produced from the isoprene and ozone reaction) was found in the ozone solution. The $\mathrm{H}_{2} \mathrm{O}_{2}$ formed in the ozone solution was measured in each experiment and was considered in the data analysis.

There is $1 \%$ acetonitrile in the reaction system. We also did experiments in absence of acetonitrile to determine if acetonitrile could affect the products formation and the kinetics. $1-\mu \mathrm{L}$ pure isoprene (equivalent to $20 \mu \mathrm{M}$ isoprene in $500 \mathrm{ml}$ solution) was injected directly into the $500-\mathrm{ml}$ ozone solution in the reactor by a syringe and a sealed Teflon stopple, and immediately the reactor (a quartz bottle) was shaken upside down for $2 \mathrm{~min}$. The subsequent experimental steps were the same as those in the reaction system in the presence of acetonitrile. The experiments were performed at one $\mathrm{pH}$ $(\mathrm{pH}=7)$ and two temperatures $\left(4^{\circ} \mathrm{C}\right.$ and $\left.10^{\circ} \mathrm{C}\right)$.

The rate constants for the aqueous ozonolysis of isoprene, methacrolein (MAC) and methyl vinyl ketone (MVK) $\left(k_{\mathrm{ISO}}=4.1 \times 10^{5} \mathrm{M}^{-1} \mathrm{~s}^{-1} ; k_{\mathrm{MAC}}=2.4 \times 10^{4} \mathrm{M}^{-1} \mathrm{~s}^{-1} ;\right.$ and $k_{\mathrm{MVK}}=4.4 \times 10^{4} \mathrm{M}^{-1} \mathrm{~s}^{-1}$, respectively, at $298 \mathrm{~K}$ ) (Pedersen and Sehested, 2001) indicated that the ozonolysis of isoprene occurred prior to the ozonolysis of MAC and MVK, when the concentrations of isoprene, MAC, and MVK were comparable in the aqueous phase. In the present study, the concentration of isoprene was $\sim 20 \mu \mathrm{M}$ and the concentration of ozone was $2-10 \mu \mathrm{M}$; that is, isoprene was in excess. Therefore, under the present experimental conditions, we expected the ozonolysis of isoprene to dominate the aqueous phase reaction.

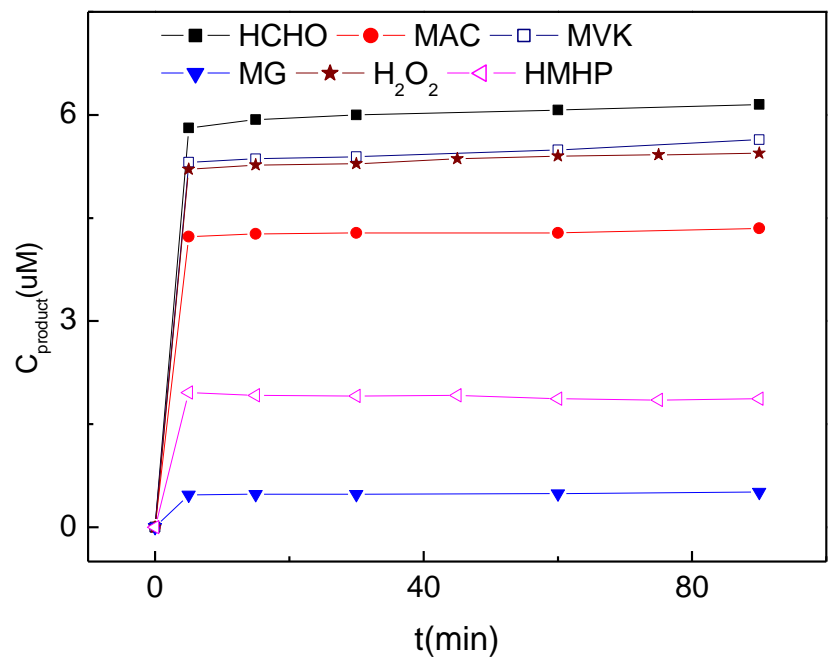

Fig. 1. The temporal profiles of the products in the aqueous isoprene ozonolysis. $T=4{ }^{\circ} \mathrm{C}, \mathrm{pH}=7.0$, initial concentration ratio of isoprene versus $\mathrm{O}_{3}, \mathrm{C}_{\mathrm{ISO}}: \mathrm{C}_{\mathrm{O}_{3}}=2: 1$.

\section{Results and discussion}

\subsection{Products and chemical stoichiometry}

The reaction of aqueous isoprene with ozone was complete within $5 \mathrm{~min}$. After this, no change was observed in the amounts of products. We then determined the amounts of carbonyls, peroxides, and organic acids for this aqueous ozonation system. We identified and quantified five products, including formaldehyde (HCHO), MAC, MVK, hydroxylmethyl hydroperoxide (HMHP), and $\mathrm{H}_{2} \mathrm{O}_{2}$. No organic acids were detected above the detection limit of $\sim 0.05 \mu \mathrm{M}$. We have done a series of experiments with an initial concentration ratio of $\mathrm{C}_{\mathrm{ISO}}: \mathrm{C}_{\mathrm{O}_{3}}$ from 2:1 to 20:1. As an example, Fig. 1 shows the temporal profiles of the products at $T=4{ }^{\circ} \mathrm{C}$, $\mathrm{pH}=7.0$, and an initial concentration ratio of $\mathrm{C}_{\mathrm{ISO}}: \mathrm{C}_{\mathrm{O}_{3}}=$ $2: 1$. It was clear that, once the isoprene and ozone solutions were mixed, a number of products formed rapidly, and then reached a plateau. A minor amount of methylglyoxal (MG) was observed when the concentration of isoprene was below or close to the concentration of ozone; in contrast, no MG was observed when the isoprene was in large excess to ozone $\left(\mathrm{C}_{\mathrm{ISO}}: \mathrm{C}_{\mathrm{O}_{3}}>10: 1\right)$, this indicated that $\mathrm{MG}$ was not a first generation product. MG is considered to be formed by the ozonolysis of MAC and MVK, which are first-generation products in the aqueous isoprene- $\mathrm{O}_{3}$ reaction system.

Next, we derived the stoichiometric ratio between isoprene and ozone in an aqueous reaction. We need to know the amount of consumed isoprene and the amount of ozone consumed by isoprene. We knew that, in the reaction system, ozone would be consumed by isoprene and by its firstgeneration products, those are MAC and MVK. The equations of MAC and MVK react with ozone were already 
Table 1. Molar yields ( $\%$ mean $\pm 2 \sigma$ ) of products in the aqueous ozonolysis of isoprene under different conditions.

\begin{tabular}{lllllll}
\hline$t\left({ }^{\circ} \mathrm{C}\right)$ & $\mathrm{pH}$ & $\mathrm{HCHO}$ & $\mathrm{MAC}$ & $\mathrm{MVK}$ & $\mathrm{HMHP}$ & $\mathrm{H}_{2} \mathrm{O}_{2}$ \\
\hline 4 & 3.0 & $58.0 \pm 2.9$ & $42.9 \pm 2.5$ & $57.9 \pm 2.7$ & $17.3 \pm 2.0$ & $49.6 \pm 4.1$ \\
& 5.4 & $59.2 \pm 1.2$ & $44.2 \pm 2.3$ & $59.1 \pm 3.2$ & $18.2 \pm 2.3$ & $51.9 \pm 1.7$ \\
& 7.0 & $59.4 \pm 3.0$ & $44.7 \pm 0.6$ & $58.4 \pm 1.8$ & $16.5 \pm 2.1$ & $54.9 \pm 3.4$ \\
10 & 3.0 & $54.9 \pm 1.5$ & $41.6 \pm 0.7$ & $57.7 \pm 2.8$ & $14.2 \pm 2.0$ & $54.3 \pm 2.5$ \\
& 5.4 & $56.5 \pm 3.4$ & $42.3 \pm 0.8$ & $55.9 \pm 2.6$ & $14.3 \pm 1.4$ & $54.3 \pm 2.0$ \\
& 7.0 & $59.2 \pm 2.6$ & $44.4 \pm 1.7$ & $57.7 \pm 2.7$ & $13.3 \pm 1.8$ & $56.6 \pm 2.7$ \\
25 & 3.0 & $53.6 \pm 2.0$ & $40.8 \pm 1.5$ & $57.5 \pm 2.9$ & $14.2 \pm 2.2$ & $54.5 \pm 3.9$ \\
& 5.4 & $54.8 \pm 3.7$ & $42.0 \pm 2.3$ & $57.9 \pm 3.4$ & $14.7 \pm 1.2$ & $52.6 \pm 2.2$ \\
\multirow{2}{*}{ Mean } & 7.0 & $54.8 \pm 1.8$ & $42.1 \pm 1.6$ & $57.2 \pm 1.8$ & $13.2 \pm 0.5$ & $52.0 \pm 1.6$ \\
\hline
\end{tabular}

Total C $94.8 \pm 4.1$

Note: Total $\mathrm{C}=\left(\right.$ Yield $_{\mathrm{HCHO}}+$ Yield $_{\mathrm{MAC}} \times 4+$ Yield $_{\mathrm{MVK}} \times 4+$ Yield $\left._{\mathrm{HMHP}}\right) / 5$.

known as follows (Chen et al., 2008):

$\mathrm{MAC}+\mathrm{O}_{3} \stackrel{(\text { aq) }}{\longrightarrow} 0.99 \mathrm{MG}+0.70 \mathrm{HMHP}+0.32 \mathrm{HCHO}$

$\mathrm{MVK}+\mathrm{O}_{3} \stackrel{(\mathrm{aq})}{\longrightarrow} 0.75 \mathrm{MG}+0.24 \mathrm{PYA}+0.69 \mathrm{HMHP}$

$+0.13 \mathrm{HCHO}+0.18 \mathrm{C}_{1}$ unknown

Where PYA represents pyruvic acid. The uncertainties of the product yields can be found in our previous work (Chen et al., 2008). The aqueous ozonolysis of MAC and MVK could produce MG with yields of $99 \%$ and $75 \%$, as shown in Eq. (1) and (2) respectively. Combining these two yields and the observed MG, we can estimate the amount of $\mathrm{O}_{3}$ consumed by MAC and MVK. In the cases with a minor mount of MG formation in the aqueous ozonolysis of isoprene, if we want to know the amount of ozone consumed by isoprene, we need to eliminate the ozone consumed by MAC and MVK. Given the rate constants of $\mathrm{MAC}-\mathrm{O}_{3}$ and $\mathrm{MVK}-\mathrm{O}_{3}$ in the aqueous phase mentioned previously (Pedersen and Sehested, 2001), one mol of MG formation in the isoprene- $\mathrm{O}_{3}$ reaction system would indicate that $0.42 \mathrm{~mol}$ of MAC and $0.77 \mathrm{~mol}$ of MVK had been consumed by $\mathrm{O}_{3}$, assuming comparable concentrations of MAC and MVK in the reaction system. Thus, one mol of MG formation indicates that 1.19 mol of $\mathrm{O}_{3}$ were consumed by the first generation products MAC and MVK. So we can get the amount of ozone consumed by isoprene by subtracting the ozone consumed by MAC and MVK from the total consumed ozone. In the cases with undetectable MG, we thought ozone was fully consumed by isoprene. Because the amount of $\mathrm{O}_{3}$ consumed by isoprene was directly proportional to the amount of (MAC+MVK) produced by isoprene, a simple linear regression was set up between ozone consumed by isoprene and (MAC+MVK) produced by isoprene (Fig. 2). The data in Fig. 2 were yielded from 72 experiments at different $\mathrm{pHs}(7.0,5.4$, and 3.0) and temperatures $\left(4^{\circ} \mathrm{C}, 10^{\circ} \mathrm{C}\right.$, and $\left.25^{\circ} \mathrm{C}\right)$. X-axis represented the amount of consumed $\mathrm{O}_{3}\left(\Delta \mathrm{C}_{\mathrm{C}, \mathrm{O}_{3}}\right)$ by isoprene in the reaction. $\mathrm{Y}$ axis represented the determined total amount of produced

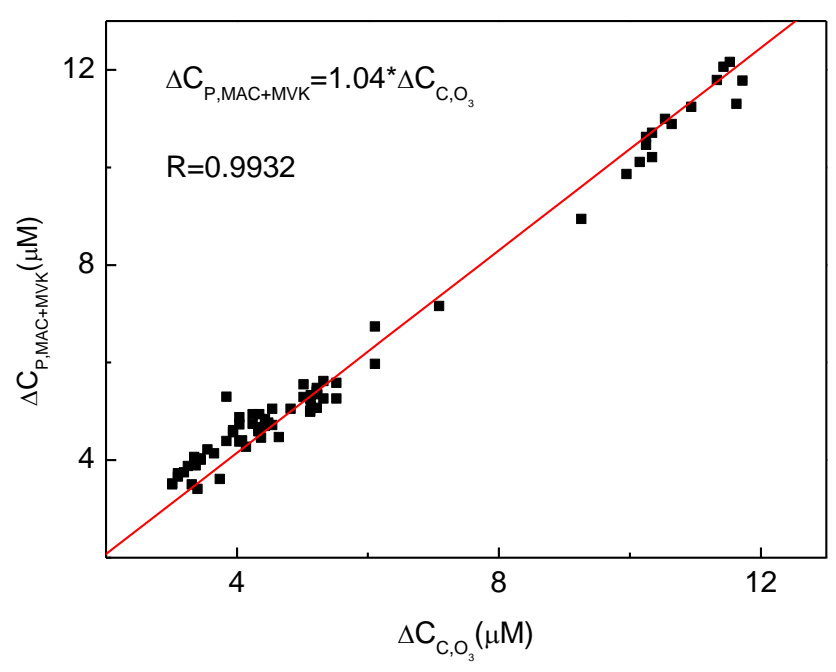

Fig. 2. The linear regression of the proportion of the formed product concentration $\left(\mathrm{C}_{\mathrm{P}, \mathrm{MAC}+\mathrm{MVK}}\right)$ versus the consumed ozone concentartion $\left(\Delta \mathrm{C}_{\mathrm{C}, \mathrm{O}_{3}}\right) \cdot \mathrm{n}=72$.

MAC+MVK $\left(\mathrm{C}_{\mathrm{P}, \mathrm{MAC}+\mathrm{MVK}}\right)$ in the reaction. On the basis of Eqs. (1), (2) and the calculation method mentioned above, the minor amount of MG formed in the reaction system was converted to MAC and MVK. This linear regression indicated that the amount of $\mathrm{O}_{3}$ consumed directly by isoprene was equal to the amount of (MAC+MVK) produced. Furthermore, it can be presumed that the consumed concentration of ozone $\left(\Delta \mathrm{C}_{\mathrm{C}, \mathrm{O}_{3}}\right)$ or isoprene $\left(\Delta \mathrm{C}_{\mathrm{C}, \mathrm{ISO}}\right)$ was related to the produced concentration of MAC + MVK ( $\left.\mathrm{C}_{\mathrm{P}, \mathrm{MAC}+\mathrm{MVK}}\right)$ as follows: $\Delta \mathrm{C}_{\mathrm{C}, \mathrm{O}_{3}} \geq \Delta \mathrm{C}_{\mathrm{C}, \mathrm{ISO}} \geq \Delta \mathrm{C}_{\mathrm{P}, \mathrm{MAC}+\mathrm{MVK}}$. Combining the result shown in Fig. $2\left(\Delta \mathrm{C}_{\mathrm{P}, \mathrm{MAC}+\mathrm{MVK}}: \Delta \mathrm{C}_{\mathrm{C}, \mathrm{O}_{3}}=1.04\right.$, approaching 1 , within experimental error, that is 2 standard deviation, $2 \sigma$ ), we assumed that $\Delta \mathrm{C}_{\mathrm{C}, \mathrm{O}_{3}}=\Delta \mathrm{C}_{\mathrm{C}, \text { ISO }}$, that is, the aqueous ozonolysis of isoprene would proceed at a stoichiometric $\mathrm{O}_{3}$ : isoprene ratio of $1: 1$. 
Considering the stoichiometric ratio of $1: 1$ between isoprene and ozone, the ozone consumed by isoprene $\left(\Delta \mathrm{C}_{\mathrm{C}, \mathrm{O}_{3}}\right)$ can be used to represent the amount of isoprene that participated in the reaction, when isoprene is in excess, and $\mathrm{MG}$ is limited to a low concentration that can be considered a minor component. Consequently, the molar yields of the products can be estimated relative to the consumed isoprene. The experimental results under different $\mathrm{pHs}(\mathrm{pH}=7.0,5.4$, and 3.0) and temperatures $\left(T=4^{\circ} \mathrm{C}, 10^{\circ} \mathrm{C}\right.$, and $\left.25^{\circ} \mathrm{C}\right)$ are summarized in Table 1. It was clear that the molar yields of peroxides and carbonyl compounds were nearly independent of the investigated $\mathrm{pH}$ and temperature conditions for the aqueous isoprene ozonolysis. The carbon yield $(94.8 \pm 4.1 \%)$ approached $100 \%$ for the investigated reaction system; this implied that most of the products were detected. We calculated the mean and standard deviation of the yields based on the 8 repeated experiments at each $\mathrm{pH}$ and temperature.

For the aqueous ozonolysis of isoprene in the absence of acetonitrile, the experimental results give the molar yields as follows: $\mathrm{HCHO}\left(60.1 \pm 2.0 \%\right.$ at $4{ }^{\circ} \mathrm{C} ; 56.2 \pm 3.2 \%$ at $\left.10^{\circ} \mathrm{C}\right)$, MAC $\left(48.1 \pm 1.5 \%\right.$ at $4{ }^{\circ} \mathrm{C} ; 50.8 \pm 4.3 \%$ at $\left.10^{\circ} \mathrm{C}\right)$, $\operatorname{MVK}\left(58.1 \pm 1.7 \%\right.$ at $4{ }^{\circ} \mathrm{C} ; 60.2 \pm 1.0 \%$ at $\left.10^{\circ} \mathrm{C}\right)$, HMHP $\left(18.2 \pm 2.7 \%\right.$ at $4{ }^{\circ} \mathrm{C} ; 16.8 \pm 2.8 \%$ at $\left.10^{\circ} \mathrm{C}\right)$, and hydrogen peroxide $\left(59.1 \pm 2.0 \%\right.$ at $4{ }^{\circ} \mathrm{C} ; 60.0 \pm 2.7 \%$ at $\left.10^{\circ} \mathrm{C}\right)$. No organic acids were observed. These yields are near to those obtained in the corresponding reactions performed in the presence of acetonitrile. The relative deviation of the corresponding yields obtained from these two types of experiments is $\leq 10 \%$. In addition, Gäb et al. (1995) had found that acetonitrile would not affect the product distribution in the aqueous ozonolysis of alkenes, only slowed the ozonolysis rate. The acetonitrile concentration presented in their work was higher than that in our work. In summary, we suggest that $1 \%$ acetonitrile used in the present study has little effect on the products formation. Because using acetonitrile stock solution of isoprene is more constant, reliable and easier to implement than using a syringe in each experiment, all the experiments discussed in the present study were performed using acetonitrile stock solution of isoprene.

In summary, the experimental results showed that the aqueous ozonolysis of isoprene proceeded at a stoichiometric ratio of 1:1; furthermore, in the aqueous isoprene ozonolysis, the consumption of one mol of ozone produced $0.68 \mathrm{~mol}$ of peroxides $\left(\mathrm{H}_{2} \mathrm{O}_{2}\right.$ : 0.53; HMHP: 0.15), $1.6 \mathrm{~mol}$ of carbonyl compounds (HCHO: 0.57; MAC: 0.43; MVK: 0.57), and organic acids were not detected. Moreover, the results of our previous study for the aqueous ozonolysis of MAC and MVK (Chen et al., 2008) showed that MAC and MVK can also be oxidized by ozone. This yielded more peroxides and secondgeneration carbonyl and acid compounds. Taken together, these results indicated that, in the earth's atmosphere where ozone is in excess compared to isoprene, one mol of isoprene can consume $2 \mathrm{~mol}$ of ozone, and produce $1.38 \mathrm{~mol}$ of peroxides, $1.67 \mathrm{~mol}$ of carbonyl compounds, and $0.14 \mathrm{~mol}$ of pyruvic acid (PYA). Therefore, the chemical stoichiometry of aqueous isoprene ozonolysis can be described as follows:

(i) First generation products of isoprene with $\mathrm{O}_{3}$ :

$$
\begin{aligned}
& \text { Isoprene }+\mathrm{O}_{3} \stackrel{(\mathrm{aq})}{\longrightarrow} 0.54 \mathrm{HCHO}+0.43 \mathrm{MAC} \\
& +0.57 \mathrm{MVK}+0.53 \mathrm{H}_{2} \mathrm{O}_{2}+0.15 \mathrm{HMHP} \\
& +0.31 \mathrm{C}_{1} \text { unknown }
\end{aligned}
$$

(ii) Complete reaction of isoprene and products with $\mathrm{O}_{3}$ :

$$
\begin{aligned}
& \text { Isoprene }+2 \mathrm{O}_{3} \stackrel{(\mathrm{aq})}{\longrightarrow} 0.81 \mathrm{HCHO}+0.86 \mathrm{MG} \\
& +0.53 \mathrm{H}_{2} \mathrm{O}_{2}+0.85 \mathrm{HMHP}+0.14 \mathrm{PYA} \\
& +0.42 \mathrm{C}_{1} \text { unknown }
\end{aligned}
$$

The uncertainties of the product yields shown in Eq. (3) can be found in Table 1 in the present study. A minor amount of carbon was not accounted for in these equations (Eqs. (3) and (4)). The chemical identity of the missing carbon is not known. Here, we tentatively assign a stoichiometry factor (0.42) which would be the appropriate molar factor if the unknown compounds were in fact C1compounds. The type of oxidant was transformed from ozone to peroxides. Moreover, these oxidant products (peroxides) were more soluble than the parents $\left(\mathrm{O}_{3}\right.$ and isoprene), and they were more likely to stay in the aqueous phase.

\subsection{Mechanism}

On the basis of the present experimental results and the available corresponding gas phase mechanism shown in Fig. 3a (Aschmann and Atkinson, 1994; Zhang et al., 2002; Aplincourt and Anglada, 2003a and b; and references therein), we propose a mechanism for the aqueous ozonolysis of isoprene (Fig. 3b). In this mechanism, the aqueous phase reaction of ozone with isoprene proceeds via the addition of ozone to one of isoprene's two double bonds to form a molozonide. One double bond in the isoprene molecule is attacked by ozone and the other double bond remains intact when isoprene is excess. This results in the formation of two kinds of molozonides. Next, the molozonide rapidly decomposes, breaking the $\mathrm{C}-\mathrm{C}$ bond and one of the $\mathrm{O}-\mathrm{O}$ bonds; this forms a stable aldehyde/ketone plus an energyrich Criegee biradical. In the case of the 3, 4 attack on the isoprene (pathway $a$ ), the stable products are MAC and $\mathrm{HCHO}$. The Criegee biradical becomes thermally stabilized and reacts with $\mathrm{H}_{2} \mathrm{O}$ to form HMHP for the al pathway and $\mathrm{CH}_{2}=\mathrm{C}\left(\mathrm{CH}_{3}\right) \mathrm{CH}(\mathrm{OOH}) \mathrm{OH}$ for the $a 2$ pathway. The $\mathrm{CH}_{2}=\mathrm{C}\left(\mathrm{CH}_{3}\right) \mathrm{CH}(\mathrm{OOH}) \mathrm{OH}$ formed via the a2 pathway is unstable, and it rapidly decomposes into MAC. Alternatively, in the case of the 1,2 attack on the isoprene (pathway $b$ ), the stable products are MVK and HCHO. The Criegee biradical becomes thermally stabilized and reacts with $\mathrm{H}_{2} \mathrm{O}$ to form HMHP for the $b 1$ pathway and $\mathrm{CH}_{2}=\mathrm{CHC}\left(\mathrm{CH}_{3}\right)(\mathrm{OOH}) \mathrm{OH}$ 
(a) Gas phase

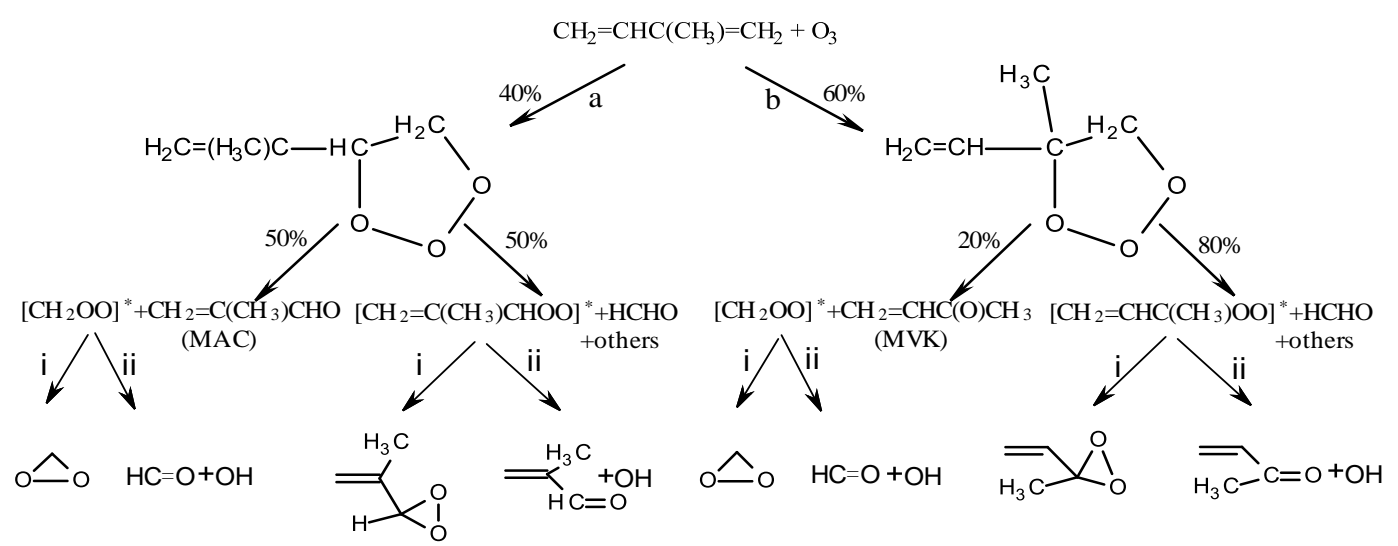

(b) Aqueous phase

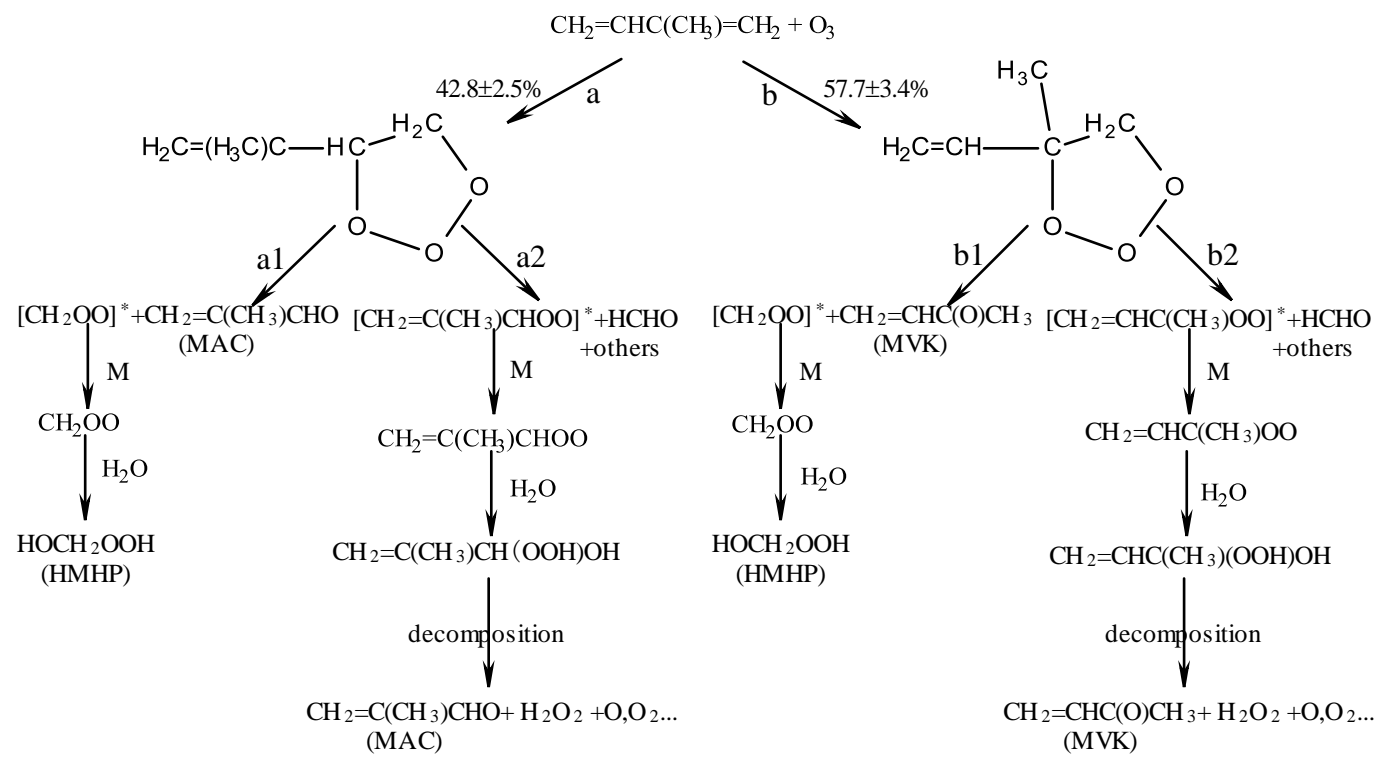

Fig. 3. Mechanisms of ozonolysis of isoprene in (a) the gas phase and (b) aqueous phase. In (a), pathway i: isomerization; pathway ii: decomposition, stabilization and bimolecular reaction.

for the $b 2$ pathway. The $\mathrm{CH}_{2}=\mathrm{CHC}\left(\mathrm{CH}_{3}\right)(\mathrm{OOH}) \mathrm{OH}$ formed in the $b 2$ pathway is unstable, and it rapidly decomposes into MVK. The expected $\mathrm{CH}_{2}=\mathrm{C}\left(\mathrm{CH}_{3}\right) \mathrm{CH}(\mathrm{OOH}) \mathrm{OH}$ and $\mathrm{CH}_{2}=\mathrm{CHC}\left(\mathrm{CH}_{3}\right)(\mathrm{OOH}) \mathrm{OH}$ products were not detected in the experiment, possibly due to their poor stability (Neeb et al., 1997; Sauer et al., 1999). The distribution of pathways $a 1$ and $a 2$ (or $b 1$ and $b 2$ ) cannot be quantified based on the present experimental results. However, in the gas phase, it has been suggested that pathway $a 2$ (or $b 2$ ), which produces a highly substituted intermediate, is dominant compared to pathway al (or b1) (Horie and Moortgat, 1991; Atkinson et al., 1995; Hasson et al., 2003).
This mechanism suggests that MVK was produced from the decomposition of the 1,2 addition complex of isoprene via pathway $b$, and that MAC was produced from the decomposition of the 3,4 addition complex of isoprene via pathway $a$. Because the combined yield of MAC and MVK approached $100 \%$, we suggest that the yields of MAC and MVK, which were determined in this study, represent the proportions of pathways $a$ and $b$, respectively; i.e., $42.8 \pm 2.5 \%$ for pathway $a$, and $57.7 \pm 3.4 \%$ for pathway $b$. In addition, every sub-pathway would produce either $\mathrm{H}_{2} \mathrm{O}_{2}$ or HMHP. $\mathrm{H}_{2} \mathrm{O}_{2}$ was produced by pathways $a 2+b 2$, and HMHP was produced by pathways $a 1+b 1$. Thus the total amount of peroxides $\left(\mathrm{H}_{2} \mathrm{O}_{2}+\mathrm{HMHP}\right)$ represents all the 
Table 2. Molar yields (\%) of MAC, MVK and peroxides in the ozonolysis of isoprene under different conditions.

\begin{tabular}{|c|c|c|c|c|c|c|c|}
\hline $\mathrm{Y}_{\mathrm{MAC}}$ & $\mathrm{Y}_{\mathrm{MVK}}$ & $\mathrm{Y}_{\text {HMHP }}$ & $\mathrm{Y}_{\mathrm{H}_{2} \mathrm{O}_{2}}$ & $\mathrm{Y}_{\text {other } \mathrm{ROOH}}$ & Gaseous & Aqueous & reference \\
\hline 41 & 18 & & & & (E) & & Kamens et al. (1982) \\
\hline 33 & 13 & & & & (E) & & Niki et al. (1983) \\
\hline $67 \pm 9$ & $26 \pm 6$ & & & & dry $(\mathrm{M})$ & & Paulson et al. (1992) \\
\hline $44 \pm 2$ & $17 \pm 1$ & & & & dry $(E)$ & & Grosjean et al. (1993) \\
\hline $38.7 \pm 3.0$ & $15.9 \pm 1.3$ & & & & dry (E) & & Aschmann and Atkinson (1994) \\
\hline \multirow[t]{4}{*}{21} & 12 & & & & dry $(\mathrm{T})$ & & Zhang et al. (2002) \\
\hline & & & 0.036 & & dry (E) & & Becker et al. (1990) \\
\hline & & $<1$ & & & dry (E) & & Neeb et al. (1997) \\
\hline & & $0.5 \pm 0.1$ & $0.7 \pm 0.3$ & $5.0 \pm 0.1$ & dry (E) & & Gäb et al. (1995) \\
\hline $34.7 \pm 0.6$ & $14.3 \pm 0.6$ & & 1 & & dry $(\mathrm{E})$ & & Sauer et al. (1999) \\
\hline \multirow{4}{*}{$39.7 \pm 1.2$} & $19.7 \pm 0.6$ & & 14 & & $75 \%$ RH at $295 \mathrm{~K}(\mathrm{E})$ & & Sauer et al. (1999) \\
\hline & & & 0.1 & & $63 \%$ RH at $297 \mathrm{~K}(\mathrm{E})$ & & Becker et al. (1990) \\
\hline & & 30 & & & $75 \%$ RH at $293 \mathrm{~K}(\mathrm{E})$ & & Neeb et al. (1997) \\
\hline & & $11.1 \pm 0.9$ & $\sim 0.1$ & $13.1 \pm 0.8$ & & $\sqrt{ }(\mathrm{E})$ & Gäb et al. (1995) \\
\hline $42.8 \pm 2.5$ & $57.7 \pm 3.4$ & $15.1 \pm 3.1$ & $53.4 \pm 4.1$ & & & $\sqrt{ }(\mathrm{E})$ & This work \\
\hline
\end{tabular}

Note: Dry indicates that the experiments were done under dry conditions $(\mathrm{RH}<5 \%)$;

$\sqrt{ }$ indicates that the experiments were done in water; $\mathrm{M}$, model study; $\mathrm{T}$, theoretical study; E, experimental study.

pathways, and thus, the yield of $\mathrm{H}_{2} \mathrm{O}_{2}+\mathrm{HMHP}$ was supposed to be $100 \%$. However, the observed total molar yield of peroxides was $70 \% .30 \%$ molar yield of peroxides was missing. We also previously observed the phenomenon of "missing" peroxides in the aqueous ozonolysis of MAC and MVK (Chen et al., 2008). This gives rise to the question of whether there are any other decomposition pathways for the energy-rich Criegee radicals; e.g., H-migration to form the $\mathrm{OH}$ radical (Zhang et al., 2002). Any OH radical that might be produced in the reaction system would be expected to react with isoprene. Huang et al. (2011) reported a much lower combined yield of MAC (11\%) and MVK (24\%) in an aqueous isoprene reaction with $\mathrm{OH}$ radicals. We have known that the combined molar yield (CY) of MAC and MVK was $35 \%$ in aqueous isoprene- $\mathrm{OH}$ reaction and $\sim 100 \%$ in the aqueous ozonolysis of isoprene (the present study) respectively. The consumed amount of isoprene by $\mathrm{OH}$ radical should be estimated. If assuming that $5 \%$ of isoprene was consumed by $\mathrm{OH}$ radical and $95 \%$ by $\mathrm{O}_{3}$, we would expect a CY with $96.8 \%$ (obtained by $5 \% \times 35 \%+95 \% \times 100 \%$ ), which was less than the observed $100 \%$ molar yield in the experiment. That is, the experimental result indicated that the isoprene- $\mathrm{OH}$ reaction was minor $(<5 \%)$ in our experiments. Clearly, further studies are necessary to investigate the identity of "missing" peroxides or other species that may contain reactive oxygen.

In the present work, we obtained the yield of each product (peroxides and carbonyls), resulting in a total carbon yield of approaching $100 \%$ in the aqueous ozonolysis of isoprene. As a comparison, the total carbon yield of peroxides and carbonyls in the gas phase reaction is much less than $100 \%$. We conclude that there is a large difference of the common product distribution between the gas phase and aqueous phase, implying that the mechanism must be different. From Fig. 3, it can be seen that the main difference between aqueous and gas phase mechanisms arises from the subsequent reaction of the energy-rich Criegee biradical (marked with *). In the aqueous phase, the energy-rich Criegee biradicals are stabilized and then reacts via bimolecular reactions with $\mathrm{H}_{2} \mathrm{O}$, while in the gas phase they can undergo decomposition, isomerization, stabilization and bimolecular reactions. Consequently, the products have fewer species and higher yields in the aqueous phase than in the gas phase. Our experimental results suggest that the condensed water is highly capable of stabilizing the energy-rich Criegee biradical.

\subsection{A comparison between aqueous and gas phase reactions}

\subsubsection{Carbonyls and peroxides}

Based on the experimental data, we could deduce the percentages of the two aqueous isoprene molozonides in the reaction; that is, the 1,2 addition complex of isoprene (PO1; pathway $b$ ) comprised $57.7 \pm 3.4 \%$, and the 3,4 addition complex of isoprene (PO2; pathway $a$ ) comprised $42.8 \pm 2.5 \%$ of the reaction (Fig. 3b.). The ratio of PO1 to $\mathrm{PO} 2$ values was consistent with that reported in the gas phase ozonolysis of isoprene. For example, Aschmann and Atkinson (1994) reported an experimental PO1:PO2 ratio of 60:40, and Zhang et al. (2002) provided computational evidence that this ratio was 59:41. Thus, we might conclude that the product distribution in the first step of ozone addition to isoprene was independent of water. This was supported by several studies that pointed out that the solvent effect on both reactants and products was energetically identical (Gligorovski and Herrmann, 2004; Monod et al., 2005).

Table 2 gives a comparison of the molar yields of major products in the gas phase and aqueous phase ozonolysis of 
isoprene. In gas phase, many experimental studies have reported yields of MAC and MVK in the ranges of 30-45\% and $10-20 \%$ respectively, whatever the relative humidity between $0 \%$ and $75 \%$. This indicates that not all the corresponding Criegee radicals might generate MAC or MVK. This could be explained by the fact that Criegee radicals participate in several competitive reactions, including stabilization to form carbonyls (MAC and MVK), isomerization to form dioxirane and organic acids, and $\mathrm{H}$-migration to form an $\mathrm{OH}$ radical (Fig. 3a). It is worth mentioning that Paulson et al. (1992) reported different yields of MAC and MVK (67 $\pm 9 \%$ and $26 \pm 6 \%$, respectively) for the gas phase isoprene- $\mathrm{O}_{3}$ reaction, based on a box model. Their combined yield of MAC and MVK approached $100 \%$. Their model appeared to include some uncertainties. For example, the proposed $\mathrm{OH}$ radical yield $(68 \%)$, which is higher than the value $(25 \%-50 \%)$ obtained in other experimental studies (Atkinson et al., 1992; Donahue et al., 1998; International Union of Pure and Applied Chemistry 2005 recommendation; Malkin et al., 2010), may have led to the high MAC and MVK yields derived from the model (Aschmann and Atkinson, 1994). In the present study of the aqueous isoprene- $\mathrm{O}_{3}$ reaction, we unexpectedly reported a $\sim 100 \%$ combined yield of MAC and MVK. To our knowledge, there is currently no other report on the yields of MAC and MVK formed in aqueous isoprene ozonolysis. Our results indicate that condensed water is highly capable of stabilizing the energy-rich Criegee biradical, and reacts with the resulting radical to generate stable carbonyls. In our previous studies on the aqueous ozonolysis of MAC, MVK (Chen et al., 2008), alpha-pinene, and beta-pinene (Zhang et al., 2009), we suggest that water plays a dual role in the aqueous reactions; that is, the water acts as both a reactant and a sink for the energy of intermediate radicals.

Like the carbonyl products, we found that the peroxides $\left(\mathrm{H}_{2} \mathrm{O}_{2}\right.$ and $\left.\mathrm{HMHP}\right)$ were produced with high yields $(68 \%)$ in the aqueous isoprene ozonolysis. Our observed peroxide yield differed from that previously reported for the gas phase and aqueous ozonolysis of isoprene (Table 2). Under dry conditions, reported HMHP yield was less than $1 \%$ in the gas phase ozonolysis of isoprene (Gäb et al., 1995; Neeb et al., 1997), while under high humid conditions $(\sim 75 \% \mathrm{RH})$, a HMHP yield of up to $30 \%$ was reported by Neeb et al. (1997). Then in the aqueous ozonolysis of isoprene, Gäb et al. (1995) observed 11 $\pm 0.9 \%$ HMHP, and here, we observed a $15.1 \pm 3.1 \%$ yield of HMHP. We speculate that the high HMHP yield under humid or aqueous conditions may have resulted from the reaction of the Criegee radical $\left[\mathrm{CH}_{2} \mathrm{OO}\right]^{*}$ with water clusters $\left(\mathrm{H}_{2} \mathrm{O}\right) n(n=$ $2, \ldots, 4)$. Computational evidence has suggested that, water clusters can be formed (primarily $\left.\left(\mathrm{H}_{2} \mathrm{O}\right)_{2}\right)$, and the rate constant of the Criegee radical reaction with water clusters $\left(\mathrm{H}_{2} \mathrm{O}\right)_{2}$ would be $\sim 100$ times higher than with unimolecule water (Ryzhkov and Ariya, 2006). Under dry conditions, Becker et al. (1990) reported a $0.036 \%$ yield of
$\mathrm{H}_{2} \mathrm{O}_{2}$ and Sauer et al. (1999) reported a $1 \%$ yield of $\mathrm{H}_{2} \mathrm{O}_{2}$. Under humid conditions, Becker et al. (1990) reported a $0.1 \%$ yield of $\mathrm{H}_{2} \mathrm{O}_{2}$ and Sauer et al. (1999) reported a $14 \%$ yield of $\mathrm{H}_{2} \mathrm{O}_{2}$. In the aqueous phase, Gäb et al. (1995) reported less than $0.1 \% \mathrm{H}_{2} \mathrm{O}_{2}$ but $13.1 \pm 0.8 \% 1$ hydroxyalkyl hydroperoxides, and we observed $53.4 \pm 4.1 \%$ $\mathrm{H}_{2} \mathrm{O}_{2}$. Despite the huge difference between the results of these experiments, we found that the yield of $\mathrm{H}_{2} \mathrm{O}_{2}$ increased with the water content increased. The increased $\mathrm{H}_{2} \mathrm{O}_{2}$ may be due to water assisted decomposition of the $\alpha$ hydroxy hydroperoxides, $\mathrm{CH}_{2}=\mathrm{C}\left(\mathrm{CH}_{3}\right) \mathrm{CH}(\mathrm{OOH}) \mathrm{OH}$ and $\mathrm{CH}_{2}=\mathrm{CHC}\left(\mathrm{CH}_{3}\right)(\mathrm{OOH}) \mathrm{OH}$, which we cannot determine by now; the products would be $\mathrm{H}_{2} \mathrm{O}_{2}$ plus MAC and MVK (Aplincourt and Anglada, 2003b).

In summary, the isoprene ozonides may encounter more water molecules in condensed water than in dry/humid air. This favors the stabilization of the Criegee radicals that formed from the decomposition of ozonides. In turn, this promots the formation of abundant peroxide and carbonyl products. Therefore, the first-generation products, including peroxides and carbonyls, were produced with high yields in the aqueous isoprene ozonolysis system compared to the gas phase reaction.

\subsubsection{Organic acids}

To our knowledge, with the ozonolysis of alkenes in the presence of water, organic acids, particularly formic acid, are considered to be another important product that accompanies the carbonyl products (Horie et al., 1994; Neeb et al., 1997; Sauer et al., 1999). These products arise from the reaction of Criegee radicals and water molecules through two pathways, the Reaction (R1) for carbonyl formation and the Reaction (R2) for organic acid formation (Gäb et al., 1985; Neeb et al., 1997; Dowideit and Sonntag, 1998; Sauer et al., 1999; Hasson et al., 2003; Jonsson et al., 2006), as follows:

$$
\begin{aligned}
& \mathrm{R}_{1} \mathrm{R}_{2} \mathrm{COO}+\mathrm{H}_{2} \mathrm{O} \rightarrow \mathrm{R}_{1} \mathrm{R}_{2} \mathrm{C}(\mathrm{OH}) \mathrm{OOH} \leftrightarrow \mathrm{R}_{1} \mathrm{R}_{2} \mathrm{C}(\mathrm{O})+\mathrm{H}_{2} \mathrm{O}_{2} \\
& \mathrm{R}_{1} \mathrm{HCOO}+\mathrm{H}_{2} \mathrm{O} \rightarrow \mathrm{R}_{1} \mathrm{HC}(\mathrm{OH}) \mathrm{OOH} \rightarrow \mathrm{R}_{1} \mathrm{C}(\mathrm{O}) \mathrm{OH}+\mathrm{H}_{2} \mathrm{O}
\end{aligned}
$$

Here, $R_{1}$ and $R_{2}$ represent hydrogen, alkyl, or alkenyl groups. The second part of Reaction (R1) was an equilibrium. The hydroxyhydroperoxide was in equilibrium with the corresponding carbonyl and hydrogen peroxide (Dowideit and Sonntag, 1998). On the opposite, the second part of Reaction (R2) is not an equilibrium, and the unstable hydroperoxides decompose into the corresponding acids. However, our result showed that no organic acid was observed in the aqueous ozonolysis of isoprene. Although Reactions (R1) and (R2) may occur simultaneously in the aqueous reaction, similar to the gas phase reaction, the condensed water may inhibit the decomposition of $\mathrm{R}_{1} \mathrm{HC}(\mathrm{OH}) \mathrm{OOH}(\alpha-$ hydroxy hydroperoxide) into water and organic acid via Reaction (R2). Instead, more $\mathrm{H}_{2} \mathrm{O}_{2}$ and carbonyls might be produced, like MAC and HCHO, via Reaction (R1). This 
explanation is supported by a theoretical investigation of the reaction between water and $\mathrm{CH}_{2} \mathrm{OO}$ and $\mathrm{CH}_{3} \mathrm{CHOO}$ biradicals (Crehuet et al., 2001; Anglada et al., 2002). In that study, the results suggest that the pathway of water-catalyzed decomposition of $\alpha$-hydroxy hydroperoxide to $\mathrm{H}_{2} \mathrm{O}_{2}$ and aldehyde is the one with a lower activation barrier compared to the pathway of decomposition to water and organic acid. In addition, in the gas phase ozonolysis of 2-methyl-3-buten-2ol, Carrasco et al. (2007) observed formic acid only under the dry condition; no formic acid was formed under the humid condition, but they observed an important increase in carbonyl compounds. They suggested that the Reaction (R1) pathway mentioned above must be more important in the presence of water. Moreover, they suggested an alternative explanation for the production of formic acid: that it was formed from the decomposition of some primary product in the gas phase ozonolysis of terminal alkenes in the presence of water vapor. However, we observed no formic acid produced from the aqueous ozonolysis of either isoprene or MAC/MVK; thus, Reaction (R2) was insignificant in this study.

\section{Conclusions and implications}

We aim to simulate the atmospheric aqueous ozonolysis of isoprene, which may potentially be an important surface reaction on atmospheric wet particles and plants. We tested ozonolysis under different relevant pHs (7.0, 5.4 and 3.0) and temperatures $\left(4^{\circ} \mathrm{C}, 10^{\circ} \mathrm{C}\right.$, and $\left.25^{\circ} \mathrm{C}\right)$, and we determined the chemical stoichiometry of the reaction. The detected products include carbonyls, peroxides, and organic acids. The molar yields of various products were independent of the investigated $\mathrm{pHs}$ and temperatures; these yields were: $56.7 \pm 3.7 \% \mathrm{HCHO}, 42.8 \pm 2.5 \% \mathrm{MAC}, 57.7 \pm 3.4 \%$ MVK, $53.4 \pm 4.1 \% \mathrm{H}_{2} \mathrm{O}_{2}, 15.1 \pm 3.1 \%$ HMHP, and undetected organic acids $(<1 \%$ estimated by the instrumental detection limit). The total carbon yield was estimated to be $94.8 \pm 4.1 \%$ on the basis of the observed products and consumed isoprene. This implied that most of the products in the reaction were detected. Our results suggest that compared to the corresponding gas phase reaction, condensed water could greatly enhance the yields of first-generation carbonyls and peroxides, but it reduced the organic acid yield to an undetectable level. Finally, we proposed a reaction mechanism that fit the experiment results.

Both $\mathrm{H}_{2} \mathrm{O}_{2}$ and HMHP act as important aqueous oxidants in the atmospheric aqueous phase in addition to serving as a source of hydroxyl $(\mathrm{OH})$ and alkoxyl $(\mathrm{RO})$ radicals. In their detailed aqueous phase organic chemistry model CAPRAM 3 for the remote scenario, Herrmann et al. (2005) pointed out that, except for the uptake of $\mathrm{OH}$ radicals into the aqueous phase (which accounts for $21.6 \%$ of the total aqueous $\mathrm{OH}$ radical), aqueous $\mathrm{OH}$ sources are highly related to the reactions of $\mathrm{H}_{2} \mathrm{O}_{2}$ (which account for $58.5 \%$ ), such as $\mathrm{H}_{2} \mathrm{O}_{2}$ photolytic decomposition and $\mathrm{H}_{2} \mathrm{O}_{2}$ Fenton reaction with $\mathrm{Fe}^{2+}$. Here, we suggest that the aqueous ozonolysis of isoprene could significantly contribute to the presence of aqueous $\mathrm{H}_{2} \mathrm{O}_{2}$. Recently, Hullar and Anastasio (2011) found that the $\mathrm{OH}$-initiated oxidation of organic compounds in aqueous solutions could, in turn, produce $\mathrm{H}_{2} \mathrm{O}_{2}$. Therefore, the aqueous isoprene reaction with ozone appears to initiate a cycle of $\mathrm{H}_{2} \mathrm{O}_{2}-\mathrm{OH}$ radical, which potentially enhances the formation of aqueous SOA considering that $\mathrm{H}_{2} \mathrm{O}_{2}$ and $\mathrm{OH}$ radicals are important aqueous oxidants for organic compounds (Carlton et al., 2006; Zhang et al., 2010; Ervens et al., 2011; Huang et al., 2011; Liu et al., 2012; Tan et al., 2012). In addition, peroxide can oxidize $\mathrm{S}(\mathrm{IV})$ into $\mathrm{S}(\mathrm{VI})$; this increases the aqueous phase acidity, and thus in favor of SOA formation from isoprene oxidation (Surratt et al., 2007).

In summary, aqueous isoprene ozonolysis consumes ozone, but generates highly-soluble peroxides, which results in a transformation of oxidants in both gas and aqueous phases, and may even amplify the oxidants. Assuming this result might be applicable to all unsaturated VOCs, it can be speculated that the aqueous ozonolysis of unsaturated VOCs would represent a significant source of aqueous phase oxidants, and furthermore, VOCs may potentially contribute to aqueous SOA via both interface and bulk reactions with the aqueous oxidants in the atmosphere.

Globally, plants represent the source of most VOCs in the atmosphere, but their emission depends on many physical and chemical factors. Biogenic unsaturated VOCs, like isoprene and terpenes, must undergo an aqueous ozonolysis on the surface of plants, within a thin film of moisture, and then produce carbonyls and peroxides, and furthermore, SOA (Hewitt et al., 1990; Altimir et al., 2006). Clearly, the extent of this reaction would differ in clean and polluted regions, because ozonolysis depends on the ambient concentration of $\mathrm{O}_{3}$. This reaction may affect the $\mathrm{O}_{3}$ and $\mathrm{SO}_{2}$ depositions onto plants. In the future, the chemistry that occurs at the vegetation-atmosphere interface should be considered for a better understanding of VOC emission and SOA formation.

Acknowledgements. The authors gratefully thank the National Natural Science Foundation of China (grants 21077003 and 40875072) and the State Key Laboratory of Environmental Simulation and Pollution Control (special fund 10Z03ESPCP) for financial support.

Edited by: R. McLaren

\section{References}

Altieri, K. E., Seitzingera, S. P., Carlton, A. G., Turpin, B. J., Klein, G. C., and Marshall, A. G.: Oligomers formed through in-cloud methylglyoxal reactions: chemical composition, properties, and mechanisms investigated by ultra-high resolution FT-ICR mass spectrometry, Atmos. Environ., 42, 1476-1490, 2008.

Altimir, N., Kolari, P., Tuovinen, J.-P., Vesala, T., Bck, J., Suni, T., Kulmala, M., and Hari, P.: Foliage surface ozone deposi- 
tion: a role for surface moisture?, Biogeosciences, 3, 209-228, doi:10.5194/bg-3-209-2006, 2006.

Anglada, J. M., Aplincourt, P., Bofill, J. M., and Cremer, D.: Atmospheric formation of $\mathrm{OH}$ radicals and $\mathrm{H}_{2} \mathrm{O}_{2}$ from alkene ozonolysis under humid conditions, Chem. Phys. Chem., 2, 215-221, 2002.

Aschmann, S. M., and Atkinson, R.: Formation yields of methyl vinyl ketone and methacrolein from the gas-phase reaction of $\mathrm{O}_{3}$ with isoprene, Environ. Sci. Technol., 28, 1539-1542, 1994.

Atkinson, R., and Arey, J.: Atmospheric degradation of volatile organic compounds, Chem. Rev., 103, 4605-4683, 2003.

Atkinson, R., Aschmann, S. M., Arey, J., and Shorees, B.: Formation of $\mathrm{OH}$ radicals in the gas phase reactions of $\mathrm{O}_{3}$ with a series of terpenes, J. Geophys. Res., 97, D5, 6065-6073, 1992.

Atkinson, R., and Carter, W. P. L.: Kinetics and mechanisms of the gas-phase reactions of ozone with organic compounds under atmospheric conditions, Chem. Rev., 84, 437-470,1984.

Atkinson, R., Tuazon, E. C., and Aschmann, S. M.: Products of the gas-phase reactions of ozone with alkenes, Environ. Sci. Technol., 29, 1860-1866, 1995.

Aplincourt, P. and Anglada, J. M.: Theoretical studies of the isoprene ozonolysis under tropospheric conditions. 1. Reaction of substituted carbonyl oxides with water, J. Phys. Chem. A., 107, 5798-5811, 2003a.

Aplincourt, P. and Anglada, J. M.: Theoretical studies of the isoprene ozonolysis under tropospheric conditions. 2. Unimolecular and water-assisted decomposition of the $\alpha$-hydroxy hydroperoxides, J. Phys. Chem. A., 107, 5812-5820, 2003 b.

Becker, K. H., Brockmann, K. J., and Bechara, J.: Production of hydrogen peroxide in forest air by reaction of ozone with terpenes, Nature, 346, 256-258, 1990.

Carlton, A. G., Turpin, B. J., Altieri, K. E., Seitzinger, S., Reff, A., Lim, H. J., and Ervens, B.: Atmospheric oxalic acid and SOA production from glyoxal: results of aqueous photooxidation experiments, Atmos. Environ., 41, 7588-7602, 2007.

Carlton, A. G., Turpin, B. J., Lim, H. J., Altieri, K. E., and Seitzinger, S.: Link between isoprene and secondary organic aerosol (SOA): Pyruvic acid oxidation yields low volatility organic acids in clouds, Geophys. Res. Lett., 33, L06822, doi:10.1029/02005GL025374, 2006.

Carrasco, N., Doussin, J. F., O'Connor, M., Wenger, J. C., PicquetVarrault, B., Durand-Jolibois, R., and Carlier, P.: Simulation chamber studies of the atmospheric oxidation of 2-methyl-3buten-2-ol: reaction with hydroxyl radicals and ozone under a variety of conditions, J. Atmos. Chem., 56, 33-55, 2007.

Chen, Z. M., Wang, H. L., Zhu, L. H., Wang, C. X., Jie, C. Y., and Hua, W.: Aqueous-phase ozonolysis of methacrolein and methyl vinyl ketone: a potentially important source of atmospheric aqueous oxidants, Atmos. Chem. Phys., 8, 2255-2265, doi:10.5194/acp-8-2255-2008, 2008.

Corrigan, A. L., Hanley, S. W., and De Haan, D. O.: Uptake of glyoxal by organic and inorganic aerosol, Environ. Sci. Technol., 44, 4428-4433, 2008.

Crehuet, R., Anglada, J. M., and Bofill, J. M.: Tropospheric formation of hydroxymethyl hydroperoxide, formic acid, $\mathrm{H}_{2} \mathrm{O}_{2}$, and $\mathrm{OH}$ from carbonyl oxide in the presence of water vapor: a theoretical study of the reaction mechanism, Chem. Eur. J., 7, 2227$2235,2001$.
Donahue, N. M., Kroll, J. H., Anderson, J. G., and Demerjian, K. L.: Direct observation of $\mathrm{OH}$ production from the ozonolysis of olefins, Geophys. Res. Lett., 25, 59-62, 1998.

Dowideit, P. and Sonntag, C. V.: Reaction of ozone with ethene and its methyl- and chlorine-substituted derivatives in aqueous solution, Environ. Sci. Technol., 32, 1112-1119, 1998.

El Haddad, I. E., Liu, Y., Nieto-Gligorovski, L., Michaud, V., Temime-Roussel, B., Quivet, E., Marchand, N., Sellegri, K., and Monod, A.: In-cloud processes of methacrolein under simulated conditions - Part 2: formation of secondary organic aerosol, Atmos. Chem. Phys., 9, 5107-5117, doi:10.5194/acp-9-5107-2009, 2009.

Enami, S., Hoffmann, M. R., and Colussi, A. J.: Prompt formation of organic acids in pulse ozonation of terpenes on aqueous surfaces, J. Phys. Chem. Lett., 1, 2374-2379, 2010.

Ervens, B., Turpin, B. J., and Weber, R. J.: Secondary organic aerosol formation in cloud droplets and aqueous particles (aqSOA): a review of laboratory, field and model studies, Atmos. Chem. Phys., 11, 11069-11102, doi:10.5194/acp-1111069-2011, 2011.

Gäb, S., Hellpointner, E., Turner, W. V., and Korte, F.: Hydroxymethyl hydroperoxide and bis(hydroxymethyl) peroxide from gas-phase ozonolysis of naturally occurring alkenes, Nature, 316 , 535-536, 1985.

Gäb, S., Turner, W. V., and Wolff, S.: Formation of alkyl and hydroxyalkyl hydroperoxides on ozonolysis in water and in air, Atmos. Environ., 29, 2401-2407, 1995.

Gligorovski, S. and Herrmann, H.: Kinetics of reactions of $\mathrm{OH}$ with organic carbonyl compounds in aqueous solution, Phys. Chem. Chem. Phys., 6, 4118-4126, 2004.

Grosjean, D., Williams II, E. L., and Grosjean, E.: Atmospheric chemistry of isoprene and its carbonyl products, Environ. Sci. Technol., 27, 830-840, 1993.

Guenther, A., Karl, T., Harley, P., Wiedinmyer, C., Palmer, P. I., and Geron, C.: Estimates of global terrestrial isoprene emissions using MEGAN (Model of Emissions of Gases and Aerosols from Nature), Atmos. Chem. Phys., 6, 3181-3210, doi:10.5194/acp-63181-2006, 2006.

Hallquist, M., Wenger, J. C., Baltensperger, U., Rudich, Y., Simpson, D., Claeys, M., Dommen, J., Donahue, N. M., George, C., Goldstein, A. H., Hamilton, J. F., Herrmann, H., Hoffmann, T., Iinuma, Y., Jang, M., Jenkin, M. E., Jimenez, J. L., KiendlerScharr, A., Maenhaut, W., McFiggans, G., Mentel, T. F., Monod, A., Prevot, A. S. H., Seinfeld, J. H., Surratt, J. D., Szmigielski, R., and Wildt, J.: The formation, properties and impact of secondary organic aerosol: current and emerging issues, Atmos. Chem. Phys., 9, 5155-5236, doi:10.5194/acp-9-5155-2009, 2009.

Hasson, A. S., Chung, M. Y., Kuwata, K. T., Converse, A. D., Krohn, D., and Paulson, S. E.: Reaction of criegee intermediates with water vapor-an additional source of $\mathrm{OH}$ radicals in alkene ozonolysis?, J. Phys. Chem. A., 107, 6176-6182, 2003.

Herrmann, H., Tilgner, A., Barzaghi, P., Majdik, Z., Gligorovski, S., Poulain, L., and Monod, A.: Towards a more detailed description of tropospheric aqueous phase organic chemistry: CAPRAM 3.0., Atmos. Environ., 39, 4351-4363, 2005.

Hewitt, C. N., Kok, G. L., and Fall, R.: Hydroperoxides in plant exposed to ozone mediated air pollution damage to alkene emitters, Nature, 344, 56-58, 1990. 
Horie, O. and Moortgat, G. K.: Decomposition pathways of the excited Criegee intermediates in the ozonolysis of simple alkenes, Atmos. Environ., 25, 1881-1896, 1991.

Horie, O., Neeb, P., Limbach, S., and Moortgat, G. K.: Formation of formic acid and organic peroxides in the ozonolysis of ethene with added water vapour, Geophys. Res. Lett., 21, 1523-1526, 1994.

Hua, W., Chen, Z. M., Jie, C. Y., Kondo, Y., Hofzumahaus, A., Takegawa, N., Chang, C. C., Lu, K. D., Miyazaki, Y., Kita, K., Wang, H. L., Zhang, Y. H., and Hu, M.: Atmospheric hydrogen peroxide and organic hydroperoxides during PRIDE-PRD'06, China: their concentration, formation mechanism and contribution to secondary aerosols, Atmos. Chem. Phys., 8, 6755-6773, doi:10.5194/acp-8-6755-2008, 2008.

Huang, D., Zhang, X., Chen, Z. M., Zhao, Y., and Shen, X. L.: The kinetics and mechanism of an aqueous phase isoprene reaction with hydroxyl radical, Atmos. Chem. Phys., 11, 7399-7415, doi:10.5194/acp-11-7399-2011, 2011.

Hullar, T. and Anastasio, C.: Yields of hydrogen peroxide from the reaction of hydroxyl radical with organic compounds in solution and ice, Atmos. Chem. Phys., 11, 7209-7222, doi:10.5194/acp11-7209-2011, 2011

Jackson, A. V. and Hewitt, C. N.: Hydrogen peroxide and organic hydroperoxide concentrations in air in a eucalyptus forest in central Portugal, Atmos. Environ., 30, 819-830, 1996.

Jacob, D. J.: Chemistry of $\mathrm{OH}$ in remote clouds and its role in the production of formic acid and peroxymonosulfate, J. Geophys. Res., 91, 9807-9826, 1986.

Jonsson, A. M., Hallquist, M., and Ljungström, E.: Impact of humidity on the ozone initiated oxidation of limonene, $\Delta 3$-carene, and $\alpha$-pinene, Environ. Sci. Technol., 40, 188-194, 2006.

Kamens, R. M., Grey, M. W., Jeries, H. E., Jackson, M., and Cole, E. I.: Ozone-isoprene reactions: product formation and aerosol potential, Int. J. Chem. Kinet., 14, 955-975, 1982.

Liggio, J., Li, S.-M., and McLaren, R.: Reactive uptake of glyoxal by particulate matter, J. Geophys. Res., 110, D10304, doi:10.1029/2004JD005113, 2005.

Yao Liu, El Haddad, I., Scarfogliero, M., Nieto-Gligorovski, L., Temime-Roussel, B., Quivet, E., Marchand, N., Picquet-Varrault, B., and Monod, A.: In-cloud processes of methacrolein under simulated conditions - Part 1: Aqueous phase photooxidation, Atmos. Chem. Phys., 9, 5093-5105, doi:10.5194/acp-9-50932009, 2009.

Liu, Y., Siekmann, F., Renard, P., El Zein, A, Salque, G., El Haddad, I., Temime-Roussel, B., Voisin, D., Thissen, R., Monod, A.: Oligomer and SOA formation through aqueous phase photooxidation of methacrolein and methyl vinyl ketone, Atmos. Environ., 49, 123-129, 2012.

Malkin, T. L., Goddard, A., Heard, D. E., and Seakins, P. W.: Measurements of $\mathrm{OH}$ and $\mathrm{HO}_{2}$ yields from the gas phase ozonolysis of isoprene, Atmos. Chem. Phys., 10, 1441-1459, doi:10.5194/acp-10-1441-2010, 2010.

Mmereki, B. T. and Donaldson, D. J.: Laser induced fluorescence of pyrene at an organic coated air-water interface, Phys. Chem. Chem. Phys., 4, 4186-4191, 2002.

Mochida, M., Katrib, Y., Jayne, J. T., Worsnop, D. R., and Martin, S. T.: The relative importance of competing pathways for the formation of high-molecular-weight peroxides in the ozonolysis of organic aerosol particles, Atmos. Chem. Phys., 6, 4851-4866, doi:10.5194/acp-6-4851-2006, 2006.

Monod, A., Chebbi, A., Durand-Jolibois, R., and Carlier, P.: Oxidation of methanol by hydroxyl radicals in aqueous solution under simulated cloud droplet conditions, Atmos. Environ., 34, 52835294, 2000.

Monod, A., Poulain, L., Grubert, S., Voisin, D., and Wortham, H.: Kinetics of $\mathrm{OH}$-initiated oxidation of oxygenated organic compounds in the aqueous phase: new rate constants, structure - activity relationships and atmospheric implications, Atmos. Environ., 39, 7667-7688, 2005.

Neeb, P., Sauer, F., Horie, O., and Moortgat, G. K.: Formation of hydroxymethyl hydroperoxide and formic acid in alkene ozonolysis in the presence of water vapour, Atmos. Environ., 31, 14171423, 1997.

Nguyen, T. B., Bateman, A. P., Bones, D. L., Nizkorodov, S. A., Laskin, J., and Laskin, A.: High-resolution mass spectrometry analysis of secondary organic aerosol generated by ozonolysis of isoprene, Atmos. Environ., 44, 1032-1042, 2010.

Niki, H., Maker, P. D., Savage, P. M., and Breitenbach, L. P.: Atmospheric ozone-olefin reactions, Environ. Sci. Technol., 17, 312A322A, 1983

Paulson, S. E., Flagan, R. C., and Seinfeld, J. H.: Atmospheric photooxidation of isoprene part II: the ozone-isoprene reaction, Int J. Chem. Kinet., 24, 103-125, 1992.

Pedersen, T. and Sehested, K.: Rate constants and activation energies for ozonolysis of isoprene methacrolein and methyl-vinylketone in aqueous solution: significance to the in cloud ozonation of isoprene, Int. J. Chem. Kinet., 33, 182-190, 2001.

Perri, M. J., Seitzinger, S. P., and Turpin, B. J.: Secondary organic aerosol production from aqueous photooxidation of glycolaldehyde: laboratory experiments, Atmos. Environ., 43, 1487-1497, 2009.

Ryzhkov, A. B. and Ariya, P. A.: The importance of water clusters $\left(\mathrm{H}_{2} \mathrm{O}\right) n(n=2, \ldots, 4)$ in the reaction of Criegee intermediate with water in the atmosphere, Chem. Phys. Lett., 419, 479-485, 2006.

Sander, R.: Compilation of Henry's law constants for inorganic and organic species of potential importance in environmental chemistry, Version 3, http://www.mpch-mainz.mpg.de/Bsander/ res/henry.html, 1999.

Sauer, F., Schafer, C., Neeb, P., Horie, O., and Moortgat, G. K.: Formation of hydrogen peroxide in the ozonolysis of isoprene and simple alkenes under humid conditions, Atmos. Environ., 33, 229-241, 1999.

Schweitzer, F., Magi, L., Mirabel, P., and George, C.: Uptake rate measurements of methanesulfonic acid and glyoxal by aqueous droplets, J. Phys. Chem. A., 102, 593-600, 1998

Schwier, A. N., Sareen, N., Mitroo, D., Shapiro, E. L., and McNeill, V. F.: Glyoxal-methylglyoxal cross-reactions in secondary organic aerosol formation, Environ. Sci. Technol., 44, 6174-6182, 2010.

Surratt, J. D., Lewandowski, M., Offenberg, J. H., Jaoui, M., Kleindienst, T. E., Edney, E. O., and Seinfeld, J. H.: Effect of acidity on secondary organic aerosol formation from isoprene, Environ. Sci. Technol., 41, 5363-5369, 2007.

Tan, Y., Lim, Y. B., Altieri, K. E., Seitzinger, S. P., and Turpin, B. J.: Mechanisms leading to oligomers and SOA through aqueous photooxidation: insights from $\mathrm{OH}$ radical oxidation of acetic acid and methylglyoxal, Atmos. Chem. Phys., 12, 801-813, doi:10.5194/acp-12-801-2012, 2012. 
Tong, C., Blanco, M., Goddard III, W. A., and Seinfeld, J. H.: Secondary organic aerosol formation by heterogeneous reactions of aldehydes and ketones: A quantum mechanical study, Environ. Sci. Technol., 40, 2333-2338, 2006.

Wang, H. L., Zhang, X., and Chen, Z. M.: Development of DNPH/HPLC method for the measurement of carbonyl compounds in the aqueous phase: applications to laboratory simulation and field measurement, Environ. Chem., 6, 389-397, 2009.

Zhang, D., Lei, W. F., and Zhang, R. Y.: Mechanism of OH formation from ozonolysis of isoprene: kinetics and product yields, Chem. Phys. Lett., 358, 171-179, 2002.
Zhang, X., Chen, Z. M., and Zhao, Y.: Laboratory simulation for the aqueous $\mathrm{OH}$-oxidation of methyl vinyl ketone and methacrolein: Significance to the in-cloud SOA production, Atmos. Chem. Phys., 10, 9551-9561, doi:10.5194/acp-10-9551-2010, 2010.

Zhang, X., Chen, Z. M., Wang, H. L., He, S. Z., and Huang, D. M.: An important pathway for ozonolysis of alpha-pinene and betapinene in aqueous phase and its implications, Atmos. Environ., 43, 4465-4471, 2009. 